\title{
Quality of Antiretroviral Drugs Analyzed in the Drug Analysis and Research Unit During
} 2000-2003

\author{
K.O. ABUGA, P. M. MWAGIRU, G.N. THOITHI, J.M. NGUYO, J.K. NGUGI, O.K. KING'ONDU, \\ H.N. MUGO AND I.O. KIBWAGE*
}

Drug Analysis and Research Unit, Department of Pharmaceutical Chemistry, Faculty of Pharmacy, University of Nairobi, P.O. Box 19676-00202, Nairobi, Kenya.

\begin{abstract}
During the period 2000-2003 the Drug Analysis and Research Unit received and analyzed 33 samples of antiretroviral drugs. Locally manufactured products accounted for $\mathbf{5 7 . 6} \%$ of the samples, while the imported drugs constituted 42.4 $\%$. The drugs consisted of single, double and triple component preparations. They were subjected to the identity, assay and dissolution tests. 30 samples $(90.9$ $\%)$ complied with compedial specifications for these tests, while 3 failed. The results obtained show that manufacture of quality generic antiretroviral drugs is achievable.
\end{abstract}

Key words: Antiretroviral, assay, dissolution, nucleoside reverse-transcriptase inhibitor

\section{INTRODUCTION}

The HIV/AIDS pandemic has contributed significantly to social and economic losses in the developing countries, whereby the majority of patients belong to the highly productive age bracket of 15-45 years. Efforts to prevent spread of the disease have not been successful in subSaharan Africa where social and religious rituals and beliefs continue to frustrate such endeavors $[1,2]$.

The antiretroviral drugs (ARVs) and drugs for opportunistic conditions are the mainstay of the management of HIV/AIDS patients. Due to resistance of HIV to single component drugs, triple therapy ARVS is the standard practice. For this purpose ARVs are classified as: nucleoside reverse transcriptase inhibitors (NRTIs), nonnucleoside reverse transcriptase inhibitors (NNRTIs) and protease inhibitors (PIs). The choice of drugs for triple therapy from the 3 classes is developed by individual countries following WHO guidelines [3,4].

To reduce the cost of ARVS most governments have resorted to compulsory licensing and hence manufacture of generic ARVs [2]. Through such programs, Brazil, India and Thailand have built a well-established system for manufacture, distribution and use of ARVs. However, there have been concerns on the quality of generic ARVs. This can only be ascertained by means of
GMP compliance and bioequivalence testing of the products [5-8].

The quality of drugs in the Kenyan market has been shown to vary with the manufacturer (brand/generic) and whether the drugs have been manufactured locally or imported. Published analytical results from Drug Analysis and Research Unit show that almost all classes of products analyzed had quality problems [913].

This paper reports on the quality of ARV drugs analyzed at DARU from 2000 to 2003 . It is the first report on the quality of antiretrovirals in the East African region.

\section{EXPERIMENTAL}

\section{Drug samples}

Drug samples and working standards were provided by the clients requesting for analysis. Samples were received from the local industry and importers intending to market the products in Kenya. The protocol for receiving samples at DARU has been described previously [14,15]. The samples analyzed consisted of pharmaceutical specialties only. 


\section{Methods}

The drug samples were analyzed using validated high performance iquid chromatography (HPLC) methods. The methods were either developed in DARU or provided by manufacturers of the products. Zidovudine was analyzed using the USP (2002) specifications [16].

\section{Quantitative determination}

The active pharmaceutical ingredient (API) content was quantified by comparison with external standards of known potency. Some of the drugs analyzed did not have compendial specifications for the tests carried out especially assay and dissolution. Therefore, the USP limits for assay (90-110\% label claim) have been applied for the results presented in this paper [16]. The dissolution test for the amount of API released into solution at 30 minutes was compared to the $70 \%$ label claim limit.

\section{RESULTS AND DISCUSSION}

The drug samples submitted for analysis consisted of single API component and combination specialties in accordance to current trends in HIV/AIDS management. Drugs belonging to the PI category were not presented for analysis. This observation reflects the behavior of ARV prescribers in Kenya, which is $\mathrm{PI}$-sparing mainly due to the adverse effects and rapid resistance to the drugs [17].

The drug samples were subjected to tests for identification, assay and dissolution as requested. The results obtained are summarized in table 1.

Table 1. Antiretroviral drugs analyzed in DARU in the period 2000-2003

\begin{tabular}{|c|c|c|c|c|}
\hline Drug(s) & $\begin{array}{l}\text { Brand/ } \\
\text { Generic }\end{array}$ & $\begin{array}{l}\text { Samples } \\
\text { Complied }\end{array}$ & $\begin{array}{c}\text { Samples } \\
\text { Failed }\end{array}$ & Total \\
\hline Lamivudine $150 \mathrm{mg}$ & Generic & 7 & 0 & 7 \\
\hline $\begin{array}{l}\text { Lamivudine syrup } \\
(10 \mathrm{mg} / \mathrm{ml})\end{array}$ & Generic & 5 & 0 & 5 \\
\hline Zidovudine $100 \mathrm{mg}$ & Generic & 3 & 0 & 3 \\
\hline Zidovudine $100 \mathrm{mg}$ & Brand & 1 & 0 & 1 \\
\hline Stavudine $40 \mathrm{mg}$ & Brand & 1 & 0 & 1 \\
\hline Stavudine $40 \mathrm{mg}$ & Generic & 2 & 1 & 3 \\
\hline Stavudine $30 \mathrm{mg}$ & Generic & 2 & 0 & 2 \\
\hline Nevirapime $200 \mathrm{mg}$ & Generic & 2 & 0 & 2 \\
\hline $\begin{array}{l}\text { Lamivudine } 150 \mathrm{mg} \\
\text { Zidovudine } 300 \mathrm{mg}\end{array}$ & Generic & 2 & 0 & 2 \\
\hline $\begin{array}{l}\text { Lamivudine } 150 \mathrm{mg} \\
\text { Stavudine } 30 \mathrm{mg}\end{array}$ & Generic & 1 & 0 & 1 \\
\hline $\begin{array}{l}\text { Lamivudine } 150 \mathrm{mg} \\
\text { Stavudine } 40 \mathrm{mg}\end{array}$ & Generic & 0 & 1 & 1 \\
\hline $\begin{array}{l}\text { Lamivudine } 102.4 \mathrm{mg} \\
\text { Stavudine } 40 \mathrm{mg}\end{array}$ & Generic & 1 & 0 & 1 \\
\hline $\begin{array}{l}\text { Lamivudine } 150 \mathrm{mg} \\
\text { Stavudine } 40 \mathrm{mg} \\
\text { Nevirapine } 200 \mathrm{mg}\end{array}$ & Generic & 1 & 0 & 1 \\
\hline $\begin{array}{l}\text { Lamivudine } 150 \mathrm{mg} \\
\text { Stavudine } 30 \mathrm{mg} \\
\text { Nevirapine } 200 \mathrm{mg}\end{array}$ & Generic & 2 & 1 & 3 \\
\hline Total number of drugs & & 30 & 3 & 33 \\
\hline
\end{tabular}


A total of 33 samples were analyzed, 22 $(66.7 \%)$ of which were single component NRTIs. Among these, lamivudine comprised 12 $(54.5 \%)$, zidovudine $4(18.2 \%)$ and stavudine 6 $(27.2 \%)$ samples, respectively. Seven samples of lamivudine submitted were in $150 \mathrm{mg}$ tablet form, while 5 were syrups. The other drugs were presented in the capsule or tablet form. Only 2 samples of nevirapine $200 \mathrm{mg}$ tablets were received, both of which complied with the tests performed.

Generic products accounted for $31(93.9 \%)$ of the samples while the 2 brands submitted were both single component NRTIs. This reflects the current govermment policy to encourage marketing of generic ARVs, which are far much affordable than the brands. Since these new generic products require analysis results for registration, it explains why they formed the bulk of samples analyzed in DARU.

The drugs analyzed were both from local (57.6 $\%)$ and imported $(42.4 \%)$ sources. The analysis results obtained show that $30(90.9 \%)$ of the samples complied with the USP specifications while 3 generic products derived from the single, double and triple component formulations (one each) failed in the assay test for stavudine.

The multicomponent formulations analyzed were $9(27.3 \%), 5$ of which were two component preparations consisting of lamivudine with either zidovudine or stavudine. The triple component formulations contained lamivudine. stavudine and nevirapine (NNRTI). Stavudine cecurred in the $30 \mathrm{mg}$ or $40 \mathrm{mg}$ strength depending on lise target group of pationts $|3|$

\section{CONCLUSION}

As more ARVs enter Kenyan market there is need for continuous market surveillance of these drugs to monitor their quality. Quality assurance during the manufacture of combination $\Lambda R V$ s needs to be implemented to minimize cases of formulation problems. Bioequivalence data should be a requirement for the registration of generic products. It is noteworthy that prescription, distribution and dispensing of ARVs in Kenya is not reliable [3]. These problems need to be addressed urgently to make ARVs available to HIV/AIDS patients countrywide. Local manufacture of these drugs will greatly reduce the cost of HIV/AIDS treatment.

\section{REFERENCES}

[1] J.M. Kiriga, L.G. Sambo, T. Okorosobo and G.M. Mwabu. Afr. J. Health Sci. 9 (2002) 27-39.

[2] Foreign Affairs Ministry, France, WHO and UNAIDS. Declaration for the Framework for Action: Improving Access to HIV/AIDS Care in Developing Countries. International Experts Meeting. 1 Dec. 2001. Paris.

[3] Ministry of Health, Kenya. Guidelines to Antiretroviral Therapy in Kenya (2001).

[4] WHO. Scaling Up Antiretroviral Therapy in Resource Limited Settings (2003).

[5] J. Galvao. Lancet 360 (2002) 18621865.

[6] WHO. Antiretrovirals Newsletter 8 (2002).

[7] K. Kraisintu, A. Aksaengsri. I4 $4^{\text {th }}$ Int. Conf. AIDS, July 7-12 (2002), Barcelona, Spain.

(8) S Houston. JIAPAC Newsletter, (2002) April/June.

[9] G.N. Thoithi, K.O. Abuga, J.M. Nguyo, G. Mukindia, O. King'ondu, J.K. Ngugi and I.O. Kibwage, East Cent. Afri. J. Pharm. Sci. 5 (2002) 28-31.

[10] 1.O. Kibwage, C.O. Ondari. I.G. Murcithi, J.K. Thuranira and J. Hoogmartens, East Cent. Afr. J. Pharm. Sci. 1 (1998) $34-38$.

[11] I.O. Kibwage, J.K. Thuranira, L. Gathu, I.M. Githiga, J.M. Nguyo, J.K. Ngugi and $\mathrm{O}$. King'ondu, East Cent. Afr. J. Pharm. Sci. 2 (1999) 32-36. 
[12] I.O. Kibwage and J.K. Ngugi, East Cent. Afri. J. Pharm. Sci. 3 (2000) 1419.

[13] F.N. Kamau, G.N. Thoithi and I.O. Kibwage, East Cent. Afr. J. Pharm. Sci. 4 (2001) $25-29$.

[14] C.K. Maitai, W.M. Kofi-Tsekpo, E. Wakori, C. Wangia, L. Mkoji and I.M. Githiga, E. Afr. Med. J. 59 (1982) 399.
[15] J.O. Ogeto, C.K. Maitai, C. Wangia, M.L. Mkoji, E. Wakori, G.K. Rutere, R.W. Mithamo, A. Ochieng' and I.M. Githiga, E. Afr. Med. J. 60 (1983) 438.

[16] United States Pharmacopeia. U.S. Pharmacopeial Convention, Inc., Rockville, MD, U.S.A. 2002.

[17] H. Murata, P.W. Hruz, Mueckler, J. Biol. Chem. 275 (2000) 20251-4. 
Ångström

Atmosphere

Atomic weight

Boiling point

Calorie

Centimeter

Central nervous system

Column chromatography

Company

Corporation

Correlation cocfficient

Coulomb

Counts per minute

Counts per second

Cubic centimeter

Cubic inch

Cubic meter

Cycles per second

Day(s)

Degrees

Celsius

Centigrade

Kelvin

Degrees of ficedom

Direct current

Disintegrations per minute

Disintegrations per second

Dyne

Flectromagnetic force

Electron spin resonance

Electron volt

Erg(s)

Feet. foot

Freezing point

(ias-liquid chromatography

Gauss

Ciram
A Gram-molecule

Atm Hertz

at. wt. High frequency

b.p. High pressure liquid chromatography

cal Hour(s)

cm Infrared

CNS Internal diameter

$\mathrm{CC}$ International unit

Co. Joule

Corp. Kilocalorie

$r$ Kilogram

C. Kilometer

cpm Kilovolt

cps Kilowatt

$\mathrm{cm}^{3} \quad$ Kilowatt-hour

in $^{3} \quad$ Liter

$\mathrm{m}^{3} \quad$ Liquid chromatography

c $s^{-1} \quad$ Logarithm

day(s) Logarithm (natural)

Mcgaelectron volts

"C Melting point

"C Meter

K Microgram

df Microliter

d.c. Micrometer

dpm Micromolar

dps Micromole

dyn Millicurie

c.m.f. Milliequivalent

ESR Milligram

iV Milliliter

$\operatorname{crg}(\mathrm{s}) \quad$ Millimeter

it Millimolar

f.p. Millimole

GLC Millisecond

(i Milliusmolar

g Minute(s)

ABBREVIATIONS

\begin{tabular}{|c|c|}
\hline $\mathrm{mol}$ & Minimum inhibitory concentration \\
\hline $\mathrm{Hz}$ & Molar concentration \\
\hline h.f. & Month \\
\hline HPLC & Nanometer \\
\hline $\mathrm{h}$ & Nanomole \\
\hline i.r. & Normal concentration \\
\hline i.d. & Nuclear magnetic resonance \\
\hline I.U. & Ohm \\
\hline $\mathrm{J}$ & Outside diameter \\
\hline kcal & Picomole \\
\hline $\mathrm{kg}$ & Probability \\
\hline $\mathrm{km}$ & Paper chromatography \\
\hline$k \mathrm{~V}$ & Proton magnetic resonance \\
\hline $\mathrm{kW}$ & Radio-frequency \\
\hline $\mathrm{kWh}$ & Relative humidity \\
\hline I & Relative standard deviation \\
\hline LC & Revolutions per minute \\
\hline $\log$ & Root mean square \\
\hline $\ln$ & Second(s) \\
\hline $\mathrm{MeV}$ & Square foot \\
\hline m.p. & Square meter \\
\hline m & Standard deviation \\
\hline$\mu \mathrm{g}$ & Standard error \\
\hline$\mu l$ & Standard temperature and pressure \\
\hline$\mu \mathrm{m}$ & Thin-layer chromatography \\
\hline$\mu \mathrm{M}$ & Ultraviolet \\
\hline$\mu \mathrm{mol}$ & Versus \\
\hline $\mathrm{mCi}$ & Volt \\
\hline $\mathrm{mEq}$ & Volt-ampere \\
\hline mg & Volt-coulomb \\
\hline $\mathrm{ml}$ & Volume \\
\hline $\mathrm{mm}$ & Volume by volume \\
\hline $\mathrm{mM}$ & Watt \\
\hline $\mathrm{mmol}$ & Watt-hour \\
\hline $\mathrm{ms}$ & Weight \\
\hline mOsM & Weight by weight \\
\hline $\min$ & Weight by volume \\
\hline
\end{tabular}

MIC

$\mathrm{M}$

month

$\mathrm{nm}$

nmol

$\mathrm{N}$

NMR

$\Omega$

o.d.

pmol

$\mathrm{P}$

H-NMR

r.f.

r.h.

RSD

rpm

r.m.s.

$s$

$\mathrm{ft}^{2}$

$\mathrm{m}^{2}$

SD

SE

S.T.P.

TLC

UV

vs

V

VA

VC

vol.

viv

W

Wh

Wi

w/w

$\mathrm{w} / \mathrm{v}$ 